4th International Scientific Conference SEC-IASR 2019,

Galati, Romania, 7th - 8th June, 2019

\title{
Curriculum References Regarding the Methodological Framework that the School Subject "Sports Training Theory" is Based On
}

\author{
Mariana ARDELEAN \\ https://doi.org/10.18662/lumproc/sec-iasr2019/03
}

How to cite: Ardelean, M. (2020). Curriculum References Regarding the Methodological Framework that the School Subject "Sports Training Theory" is Based On. In S. Marin \& P. Moisescu (vol. eds.), Lumen Proceedings: Vol. 12. 4th International Scientific Conference SEC-LASR 2019 (pp. 20-29). Iasi, Romania: LUMEN Publishing House.

https://doi.org/10.18662/lumproc/sec-iasr2019/03 


\title{
Curriculum References Regarding the Methodological Framework that the School Subject "Sports Training Theory" is Based On
}

\author{
Mariana ARDELEAN 1
}

Abstract

The school subject "Sports Training Theory" (STT), which is present in the national curriculum at the fifth core curriculum - "Physical Education and Sports", has the role to form and develop the cognitive competencies tools that students from sports program high schools shall be able to use, in order to make their actions efficient during the classes, as well as during training and competitions. The present research has intended to analyse the methodological framework on which the STT subject bases on, relating it with its curriculum products. There were outlined a series of non-complying aspects in regard to a modern and competent educational system. Using symbolically graphic operators (+) for positive notes that come out from this study and (-) for the negative notes or the ones that require remediation, the image of the school subject STT is presenting as followed: frame syllabus (+), subject syllabus (+, -), methodological guidance for the subject syllabus enforcing (-), specialized methodology (-), textbooks (+), alternative textbooks (-), teaching auxiliaries (-). The obtained results from this research play the prominent part of an "anamnesis", in the way that appropriate institutions/ organizations that have competence in this field and hold the necessary tools to act, shall not remain still to the pointed issues which haven't been solve up to present. Moreover, they have to make efforts to reorganizel relocate the STT school subject on more accurate background, taking into consideration the fact that the curriculum structure and content shall be determined by task analysis, and shall include proficiency objectives including how those objectives shall be met.

Keywords: Sports Training Theory; frame syllabus; curriculum products; sports program high schools.

\footnotetext{
1 University of Medicine, Pharmacy, Sciences and Technology of Târgu Mureş, Gh. Marinescu, 38, 540139, Târgu Mureş, Romania. 


\section{Introduction}

Together with the other school subject from the core curriculum and which contribute to build up the students' personalities, the school subject STT has the role of offering to the subjects the specific knowledge, concepts and attitudes that all combined will form the self- motivation to become a performance achieving sportsman and a socially incorporated citizen. The knowledge gained from studying this subject contributes to stimulate interest in science, in forming logical thinking and critical mind, developing the students' intellectual capacities, according to the requests of his practiced sport discipline and personal desires/wishes.

Being an integrative subject in a physically active domain, deeply evaluating, the contents of STT school subject aims both the cognitive, wishful side and the rational- affective one, pushing forward the intellectual skills of a sportsman, the structure of critical spirit, of logical, flexible thinking, the capacity of presenting arguments and interpreting objectively the framework of the science called Sports.

\section{Problem Statement}

Together with the other school subjects that contribute to the developing cognitive abilities and the shaping of students personalities, an essential role rests upon the School subject STT If in 1992, the starting up year of vocational sports program high schools, students had in their scholar timetables, weekly classes of what Gh. Cârstea called "Theory" (2000) [1], today the STT school subject justified stands in the National frame syllabus as an integrative, deeply assessing discipline, having the aim to endow students with that knowledge, those concepts and attitudes, that would determine them to act in awareness, with maturity, in order to obtain valuable performances, enhancing their chance to consciously and actively participate to their own forming and self-forming process.

Regarding the fact that until present days there were no scientific approach that could illustrate the methodological and normative framework that the subject STT is based on, a comparative study was required, a comparative analysis of the actual status of this subject in relation to the curriculum products, in order to identify the positive aspects, but also the negative ones, that leave a bad mark on the quality of the teaching-learning process. 


\section{Research Questions/Aims of the research}

The aim of this research is to analyze the structure of the methodological framework that supports the subject STT, in the context of the wanted final products in the sports program high schools, vocational profile. Based on these coordinates, in the present study, the following objectives were established:

- the illustration of the organizational specificity of the present education system, in the STT context, by doing a comparative analysis of the present status of this school subject, in relation to the curriculum products;

- the identification of the deficient aspects that leave a mark on the quality of the teaching- learning process.

\section{Research Methods}

The scientific methods used in the research were: bibliographic documentationand the method of analysing the teaching-learning process documents.

Bibliographic documentation has led to the identification and the selection of the most relevant information with theoretical and applicative value on the subjected matter.

For a higher degree of objectivity of this research, it was necessary to study and analyse school papers (educational framework, school analytical programs, school textbooks and methodologies, methodological guides that apply to school programs and auxiliaries). This process ensured a way to establish with accuracy a normative framework for the STT school subject, in report with every curricular product and the follow-up accomplishment of this research [2], [12].

\section{Findings}

In order to scan the actual status of the STT subject, considering the curriculum products, we will use graphic operators, writing symbols like "+" for those papers that this subject could make reference to and "-" for the deficient aspects that require improvement and correction. In this context, the overall curriculum figure of speech that supports the considered subject, shows a series of positive $(+)$ and negative $(-)$ data. 


\subsection{The frame syllabus ( + )}

In the frame syllabus the subject "Sport Training Theory" finds itself at the fifth curriculum area - Physical Education and Sports".For thesports program high schools, vocational line, the frame syllabus sets a differentiated syllabus for the inferior as well as the superior high school cycle in STT classes, having its own column in the class grade book. Two classes / week are assigned to this subject, the teaching process being made with the entire class of students, regardless the specialization. The assessment is achieved using the consecrated forms in the educational system: periodically, at the end of each semester (by 50 minutes written test papers), at the Sport Training Theory National Olympiad (stages: school level, county level, national level) and also by achieving the professional certificate that allows students to coach in certain conditions [4], [5], [6], [10], [11].

\subsection{The subject syllabus (+, -$)$}

The document that sets the content of the teaching process in the school is the subject syllabus. This official document that describes the educational framework for each school subject during a determined school cycle- of 4 year study period is considered to be the most important document for a teacher, as it guides him during all the stages of the teaching process.

The STT school syllabuses, conceived in accordance with the curriculum, are official documents elaborated by the Curriculum National Council. The beginnings of the STT educational reform set off the elaboration of new school programmes in the year 2006. For the STT school subject, the analytical programmes for the inferior and superior high school cycle aim to the vocational line classes, sports profile, all specializations [7], [8], [9].

The subject syllabuses for the $9^{\text {th }}$ to $12^{\text {th }}$ grade have been analyzed considering criteria that made reference to content selection according to the development level of the addressed subjects, to the formative value of the content aspects, to their value for the permanent education of students, to the personalized demands in certain domain, to the pedagogical possibilities in passing over the contents to students who are in certain intellectual and social stages of development.

The main argument that substantiates the positive aspect $(+)$ of the subject syllabuses is sustained by the fact that in its structure there are specific competencies for each year of study (derived from the general competencies), and to each specific competence it is associated contents that 
contribute to its achievement (or it should!), according to the logic that sustain the theoretical science and the sport training methodology.

Regarding the nowadays content of the subject syllabuses, the main problem is to reconcile, on one hand, the need to assimilate relevant information for the knowledge and practice of the sports trainer profession and on the other hand, the limited power of the student's mental and physical abilities.

Although one of the purposes of the reform was to have uncluttered school programmes, the reality seem that it hasn't fulfilled these expectations. Until now, the STT subject has suffered no change, though multiple signals were drawn by the teachers involved in the teaching process of this school discipline. These aspects have been signaled during the discussions with the representatives of the Central Committee of the Sport Training Theory National Olympiad, thathas been ongoing since 2006.

The analysis of the subject syllabuses at the $9^{\text {th }}-12^{\text {th }}$ grades pointed out a series of major deficiencies (-).

To exemplify, for the inferior high school cycle (grades $9^{\text {th }}$ and $10^{\text {th }}$, the following aspects are presented:for the $9^{\text {th }}$ grade, the " 3.3 . competence: Measuring the characteristics of effort", by the associated contents from the syllabus, it does not integrate within, on one hand, the effort in relation to weariness and recover period of time, and on the other hand, the syllabus does not request the approach of some terms such as fatigue, pause, the relation between return-recover-reset; for the $10^{\text {th }}$ grade, the specific competence "6.1. The distinction between attributions and the types of relations of the local and central organizational structures "shows contents which do not correspond, from a logical point of view; the local organizational units of sports schools, are found in the 9th grade school syllabus, with the same sequence number, "6.1".

From the same perspective, for the superior high school cycle, the ones that draw attention upon them are the form and content elements from the school syllabuses, for both $11^{\text {th }}$ and $12^{\text {th }}$ grade: for the $11^{\text {th }}$ grade, the competence "3.2. The rationale for the use of the main selection criteria in the practiced sports discipline"- regarding the selection in sport, aims the contents from which is missing the learning unit that best reflects the argument of using the main selection criteria for the practised sports type: "designing the pattern lesson"; for the $12^{\text {th }}$ grade, the specific competence "5.1. Establishing the efficiency level of technical-tactical drills, in order to be assessed", presents some inaccuracies. Due to the matter that in sports training, it is not evaluated only the level of technical- tactical preparation, some conceptual inaccuracies were traced throughout this competence and its contents. The $5^{\text {th }}$ general competence presented in the curriculum and to 
which it subordinates the specific competence 5.1. "Appropriate use of methods and techniques specific to investigation, interpretation and evaluation/self-evaluation sports training levels", refers directly to the movement qualities, which are "distributed" on each year of study, from the current syllabus of the $12^{\text {th }}$ grade, and in which were overlooked the specific competences and their contents related to the coordinating skills, mainly mobility and flexibility.

The imprecisions and/or generalities much too ample, considering the manner in which the specific competences and associated contents are formulated, expose teachers to some vulnerabilities difficult to compensate with only their professional experience:

- for each level of training there are a series of specific competencies which do not reflect entirely the associated contents, being situations where the proposed content in the syllabus is repeated in the next year's programme, aiming at other objectives and competencies;

- the scientific content of the syllabus is not organized on a gradual basis, both within the same programme and at the school cycle level;

- not all contents are selected and organized according to students' learning potential, corresponding to each age group; work is done with complex accents that address only a certain class of students, the rest being exceeded by the amount and quality of the information that they should have processed;

- the subject syllabuses address only to learners who are intrinsically motivated to learn and who are able to internalize abstract information at a sustained rate throughout the school year;

- not all contents prove scientific rigour, cultural relevance and up-todate information;

- if some contents have a high motivational value, proposing knowledge that is likely to trigger and support students' epistemic and cultural motivation, the taste for study with the expansion of the knowledge horizon, and other contents are unappealing.

\subsection{Textbooks (+), alternative textbooks (-)}

Designed as an instrument of teaching, but mostly of learning, textbooks represent the "pedagogical environment" for the presentation of scientific knowledge [13]. Course books at STT subject concretize the school curricula, being developed for each level of training. Being the first manuals officially accredited by the Ministry of National Education to the STT subject, they had a positive impact on both students and teachers in the initial phase, therefore they were unconditionally accepted by all the 
beneficiaries/ users. However, over the years, the practical work with the manual (in class and at home) has led to the identification of many shortcomings that have been reflected directly in the teaching-learning and evaluation process, being felt especially by teachers (out of their concern!) and less by the students.

Because a "unique" manual that meets the requirements of each beneficiary (teacher, student) cannot be conceived, the quality of any manual will always be questioned and leave room for many interpretations, starting with its content and pedagogical processing and ending with drafting and illustration. Any complaints about the way textbooks are built remain in the personal dissatisfaction stage, because without a legal framework, nothing can be changed in the triad: course book- plan-framework. In other words, from a reformist perspective, editing a new type of textbook would require the development of a new school syllabus, and this, in return, would be conditioned by the design of a new curriculum framework.

However, as an expression of the educational democracy, alternative textbooks have come up in the Romanian curriculum. If in the other school disciplines the teachers' psycho-pedagogical skills are also emphasized by the freedom of choice (from a relatively generous offer) for a particular manual that best fits the intellectual characteristics of the class of students, but also by the pedagogical teaching style, the STT subject is still unresolved, this discipline being among the few (if not the only one) that has a single course book.

\subsection{Specialized Methodology (-) and methodological guide for the application of school syllabus (-)}

The specialized methodology and the methodological guide for the application of the school syllabus are the curricular products which, through their lack, deprive the TST school subject.

The specialists in this domain should direct their attention towards the development of a specialized methodology, because the complexity of teaching this school subject is also due to the fact that, in a great extent, the content of the curriculum has a correspondent in the practical activity, aiming, on one hand, sports as a physical-motion phenomenon, but also as a psycho-social phenomenon. Over time, there have been multiple signals on how to elaborate such a work on teaching the subjected school discipline, but things have remained at the stage of the project or promise from those who have competencies on this area, at present being only methodological suggestions at the level of each analytical programs. The issue is all the more sensitive as, in the absence of a psycho-pedagogical work of such 
importance, the quality of the educational act is diminished, and the risk of falling into some methodical skews is large, with easy to anticipate long-term effects, both for teachers but mostly for students.

Another pointed out aspect is the lack of other curricular support that concretely explains the directions and ways to act towards the coordinates envisaged by the educational policies - the methodological guides to apply the school curriculum. Paradoxically, prior to the development of the new school curriculum (2006), there was a guide, written in 2000, which covered both the quality of course book and methodological guide [3]. Designed according to other psycho-pedagogical reference points, the current analytical programs cannot be related to the old methodological guide, hence the need to develop such a curricular support.

\subsection{Teaching auxiliaries (-)}

In the STT syllabus, the teaching auxiliaries are also found. They are missing in the sense that, until now, at national level, there have been no "original models" recognized by the competent forums, leaving it to each teacher to devise their own didactic materials to ensure the teaching learning or assessing.

\section{Discussions}

Massively exposed in mass-media, criticized by critics and praised by authors or supporters, the content of the curriculum and their practical application are only some of the most pointy problems of the Romanian educational system, as an educational systems gains more formative valences at first by judiciously selecting its content. Starting from this consideration, the authors of upcoming school curricula should judge between what constitutes the essential content of the STT subject and what could be accepted to be forgotten or set aside.

The current subject syllabus have as main target to design learning content from the point of view of a capacity-based approach and attitudes, achieving a vertical and horizontal coherence within the curriculum. Given the situation in which the subjects will have systematic training and education at the class, the gene pool they have intellectually will be developed at a higher level and then transformed into skills to support their practical work. However, in order to achieve this major goal, teachers should have an efficient, transparent and high-quality methodological support that allows them to continuously improve their teaching and assessing techniques. 


\section{Conclusions}

In accordance with the purpose of the research, the targeted objectives were achieved, the methods used facilitating the exploration of the complex process of curricular analysis.

The analysis of the curricular methodological framework led to the determination of the positive $(+)$ marks on which the teaching-learning and evaluation process of the STT subject is based on and identifying stringent issues that need to be corrected (-). Along with the negative examples being reported, the pedagogical logic oblige us to forward proposals/solutions that constitute a starting point for the authorities that have legal competencies to make an efficient and transparent framework. Therefore, for the $9^{\text {th }}$ grade, the specific competence 3.3.: elaborating a specific competence that would replace that existing one in the current syllabus, such as: "Measuring the effortweariness - recover relationship in the practiced sport discipline"; designing contents and learning units specific to the newly stated competence: weariness: the steps that lead to weariness, types of weariness, causes of weariness; return-recover-reset relationship. For the $10^{\text {th }}$ grade, to the competence 6.1.:to correct or replace the mistakenly written competence with a new one, for example: "Identifying the organizational structures of school sport, at national level". For the $11^{\text {th }}$ grade, to the specific competence 3.2.: completing the contents with a new learning unit; together with "the selection system" and "selection criteria", it should be also found the "selection pattern". For the $12^{\text {th }}$ grade, to the specific competence5.1.:to design a specific competence that incorporates the whole assessing concept and to replace the current one, such as: "Evaluating the level of training and performance achieved within the practiced sports discipline"; to specify new contents and learning units for the newly designed specific competence, such as: evaluation criteria - assessing: types of evaluation, tests in order to assess movement skills, specific to the practiced sports discipline.

The correction of exposed inconsistencies in the school curriculum, the design of alternative textbooks for each level of training, a specialized methodology, a school curriculum guide and teaching aids to support learning and evaluation, remain open for the authorities and the specialists in the field, the only ones who have the legal tools needed to solve these problems.

\section{References}

[1] Cârstea Gh. Teoria şi metodica educației fizice şi sportului pentru examenele de definitivat şi gradul didactic II. Bucureşti: ANDA; 2000. 198 p. 
[2] Joița E, Ilie V, Vlad V, Frăsineanu E. Pedagogie şi elemente de psihologie şcolară pentru examenele de definitivare şi obținerea gradului didactic II. Craiova: Arves; 2003. 450 p.

[3] Ministerul Educației Naționale. Pregătire sportivă teoretică. Ghid metodologic de aplicare a programei şcolare. Bucureşti: Consiliul Naţional pentru Curriculum; 2000.

[4] Ministerul Educației şi Cercetării. ANEXA la Ordinul comun M.E.C M.M.S.S. cu nr. MEC 4330 din 2002 şi nr. M.M.S.S. 534 din 2002 privind aprobarea Metodologiei de organizare şi desfăşurare a examenului pentru certificarea competențelor profesionale în învățământul liceal, filierele tehnologică şi vocațională. Bucureşti.

[5] Ministerul Educației şi Cercetării. Anexa nr. 3 la OMECT nr. 5723 /23.12.2003 privind aprobarea disciplinelor de specialitate din curriculumul diferențiat pentru clasele a IX-a - a X-a, filiera vocațională, profil sportiv. Bucureşti.

[6] Ministerul Educaţiei, Cercetării, Tineretului şi Sportului, prevederile aliniatului (6) al Art. 57 din Regulamentul de organizare şi funcționare a unităților din învățământul preuniversitar şi aprobat prin Ordinul M.Ed.C. nr. 4925/08.09.2005. Bucureşti.

[7] Ministerul Educației şi Cercetării. Programe şcolare pentru ciclul superior al liceului, Pregătire sportivă teoretică, Filiera teoretică, profil sportiv, toate specializările, Clasa a XI-a, Aprobat prin ordin al ministrului Nr. 3252/ 13.02.2006.Bucureşti: Consiliul Național pentru Curriculum; 2006.

[8] Ministerul Educației şi Cercetării. Programe şcolare pentru ciclul inferior al liceului, Pregătire sportivă teoretică, Filiera teoretică, profil sportiv, toate specializările, Aprobat prin ordin al ministrului Nr. 3432/ 15.03.2006. Bucureşti: Consiliul Naţional pentru Curriculum; 2006.

[9] Ministerul Educaţiei şi Cercetării. Programe şcolare pentru ciclul superior al liceului, Pregătire sportivă teoretică, Filiera teoretică, profil sportiv, toate specializările, Clasa a XII-a, Aprobat prin ordin al ministrului Nr. 5959/22.12.2006.Bucureşti: Consiliul Național pentru Curriculum; 2006.

[10] Ministerul Educației şi Cercetării. Ordin nr. 4115/11.05.2009 privind aprobarea Metodologiei de organizare şi desfăşurare a examenului pentru certificarea competențelor profesionale în învățământul liceal, filiera vocațională. Bucureşti; 2009.

[11] Ministerul Educațieişi Cercetării. Metodologia-cadru de organizare şi desfăşurare a competițiilor şcolare, aprobată prin Ordinul Ministrului Educației Tineretului şi Sportului nr. 3035/10-01.2012. Regulament specific privind organizarea şi desfăşurarea Olimpiadei de Pregătire Sportivă Teoretică.Bucureşti; 2012.

[12] Negreț-Dobridor I. Teoria generală a curriculumului naţional. Iaşi: Polirom; 2008. 440 p.

[13] Nicola I. Tratat de pedagogie şcolară. Bucureşti: Editura Didactică şi Pedagogică R.A.; 1996. 485 p. 